\title{
Verrucous haemangioma: a diagnosis to consider
}

\author{
Tiago Mestre, ${ }^{1}$ Cristina Amaro, ${ }^{1}$ Isabel Freitas ${ }^{2}$
}

1 Department of Dermatology, Hospital Curry Cabral, Lisbon, Portugal

${ }^{2}$ Department of Dermatology, Hospital Biatriz Angêlo, Lisbon Portugal

\section{Correspondence to} Dr Tiago Mestre, tiago.g.mestre@gmail.com

Accepted 16 May 2014

\section{DESCRIPTION}

The authors report a case of an 11-year-old boy with a congenital lesion on the left leg, initially described as a blue macule which progressed to a verrucous pigmented plaque (figure 1). MRI (figure 2) showed local infiltration of the lower dermis and subcutaneous tissue. Histopathological examination (figure 3) showed hyperkeratosis, irregular acanthosis, papillomatosis and vascular proliferation in the superficial dermis, deep dermis and subcutaneous fat tissue compatible with a verrucous haemangioma ( $\mathrm{VH})$.

$\mathrm{VH}$ is a rare congenital vascular anomaly. The International Society for the study of vascular anomalies classifies vascular anomalies as vascular neoplasms or vascular malformations. In verrucous haemangiomas, categorisation as a neoplasm or malformation cannot be established definitely. Its classification is still unclear because it exhibits clinical features similar to those seen in vascular malformations, but expresses an immunoprofile similar to vascular neoplasms (WT1 and Glut-1 positivity). ${ }^{1}$

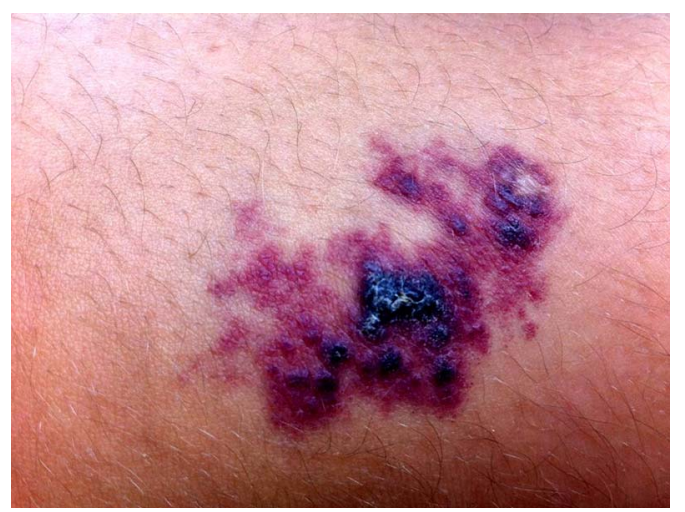

Figure 1 Located at the upper end of the anterior aspect of the left leg, we observed a $4.5 \times 3.9 \mathrm{~cm}$, irregular hyperkeratotic bluish plaque with elastic consistency, without murmur or increased temperature.

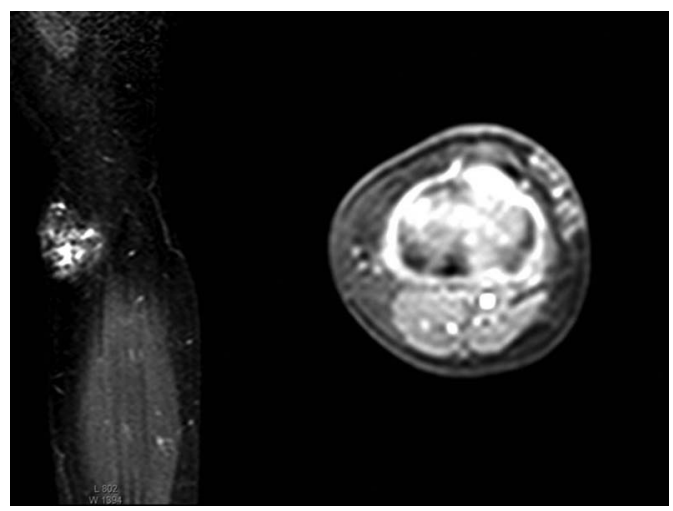

Figure 2 MRI showing serpiginous vascular structures, occupying almost the entire subcutaneous tissue.

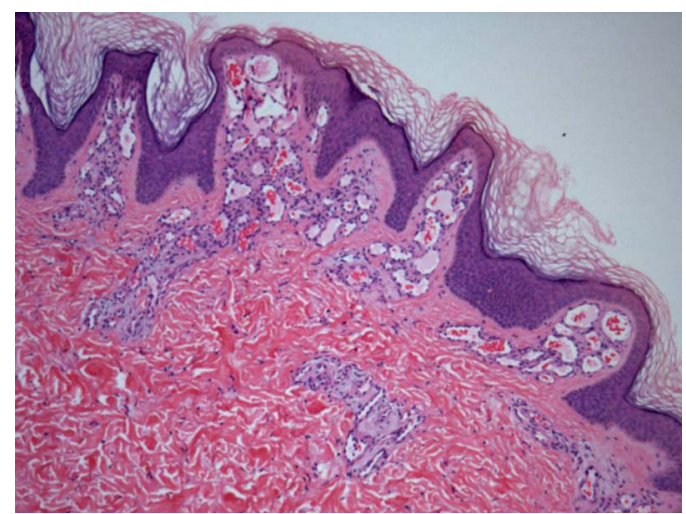

Figure 3 Histology $(H \& E \times 40)$ showing hyperkeratosis, irregular acanthosis, papillomatosis and vascular proliferation in the superficial dermis, deep dermis and subcutaneous fat tissue. Attending to clinical history and histology, the immunostaining for glucose transporter-1 (Glut-1) which is focally expressed by the endothelium of verrucous haemangiomas was not performed.

The lesion is usually noted at birth or during childhood but unlike other haemangiomas does not undergo spontaneous involution. They can be found in the head, trunk and limbs, although in the literature the most commonly reported sites are the legs. It initially appears as a bluish macule that later gets an erythematous-violaceous colour, and following trauma and secondary infections, often evolves into a verrucous plaque/nodule. ${ }^{2}$

The principal differential diagnosis is performed with angiokeratoma and circumscribed lymphangioma. The final diagnosis of verrucous haemangioma is performed by histopathological examination, although the clinical correlation is necessary for the correct diagnosis. Histologically they resemble angiokeratoma, however, in contrast to this, the vascular spaces in $\mathrm{VH}$ also affect the lower dermis and subcutaneous tissue. ${ }^{3}$

\section{Learning points}

- Verrucous haemangioma (VH) classification is still unclear because it exhibits clinical features similar to those seen in vascular malformations, but expresses an immunoprofile similar to vascular neoplasms.

- VH should be considered in the differential diagnosis of vascular lesions of the lower limb. The main differential diagnosis because of its clinical and histological similarities is with angiokeratoma.

- Conventional surgery or a combination of surgery with sclerotherapy and laser are reported in the literature as treatment of $\mathrm{VH}$. 
Early diagnosis and intervention may be important in selected patients to a better cosmetic outcome. Owing to their deep component it requires a wide excision to ensure free margins and possible recurrences. Conventional surgery, sclerotherapy, laser or a combination of these techniques can be tried. ${ }^{4}$

Contributors TM helped with the conception, design, analysis and interpretation of the data, drafting of the manuscript, and gave the final approval; CA was involved in the acquisition of the data, analysis and interpretation of the data and gave the final approval; IF did the critical revision of the manuscript and gave the final approval.

Competing interests None.
Patient consent Obtained.

Provenance and peer review Not commissioned; externally peer reviewed.

\section{REFERENCES}

1 Trindade $\mathrm{F}$, Torrelo A, Requena $\mathrm{L}$, et al. An immunohistochemical study of verrucous hemangiomas. J Cutan Pathol 2013:40:472-6.

2 Pavithra $\mathrm{S}$, Mallya $\mathrm{H}$, Kini $\mathrm{H}$, et al. Verrucous hemangioma or angiokeratoma? A misdiagnosis. Indian I Dermatol 2011;56:599-600.

3 Kaliyadan $F$, Dharmaratnam $A D$, Jayasree $M G$, et al. Linear verrucous hemangioma. Dermatol Online J 2009;15:15.

4 Popadic M. Evolution of verrucous hemangioma. Indian J Dermatol Venereol Leprol 2012;78:520.

Copyright 2014 BMJ Publishing Group. All rights reserved. For permission to reuse any of this content visit http://group.bmj.com/group/rights-licensing/permissions.

BMJ Case Report Fellows may re-use this article for personal use and teaching without any further permission.

Become a Fellow of BMJ Case Reports today and you can:

- Submit as many cases as you like

- Enjoy fast sympathetic peer review and rapid publication of accepted articles

- Access all the published articles

- Re-use any of the published material for personal use and teaching without further permission

For information on Institutional Fellowships contact consortiasales@bmjgroup.com

Visit casereports.bmj.com for more articles like this and to become a Fellow 